\title{
深頸部感染症の臨床的検討
}

$\begin{array}{rrrrr}\text { 那須 } & \text { 隆 } \cdot \text { 小池 } & \text { 修治・稲村 } & \text { 博雄 } \cdot \text { 鈴木 } & \text { 豊 } \\ \text { 赤塚 } & \text { 直子 - 伊藤 } & \text { 吏 } \cdot \text { 中村 } & \text { 正 } \cdot \text { 青柳 } & \text { 優 }\end{array}$

\section{A Clinical Study on Deep Neck Infections}

\author{
Takashi Nasu, Syuji Koike, Hiroo Inamura, Yutaka Suzuki, \\ Naoko Akatsuka, Tsukasa Ito, Tadashi Nakamura and Masaru Aoyagi \\ (Yamagata University School of Medicine)
}

\begin{abstract}
Between 1982 and 2001, 50 cases of deep neck infection were treated in our hospital. This study reviewed the management of deep neck infection, referring to primary focus, pathogenic bacteria, administration of antibiotics and surgical treatment. Fifty cases were classified by two groups according to the duration of admission, the severe group (more than 2 weeks) and the mild group (less than 2 weeks). Characteristics of these two groups were compared to identify factors affecting severity. This investigation indicated that the factors which affect severity were age, interval from onset to initial diagnosis, site of abscess formation and immunosuppression.
\end{abstract}

Key words : deep neck infection, cervical abscess, staging of cervical abscess, complication

\section{はじめに}

深頸部感染症は，抗生剂の普及により頻度が減少して きたといわれているが1)，現在でも重症化し生死にかか わる深刻な状態に陥ることがまれに経験される．深頸部 膿瘍や縱隔膿瘍などの重症深頸部感染症の症例報告は今 日でも決して少ないものではない。これは深頸部感染症 の頻度は減少しているにもかかわらず，重篤な深頸部感 染症に移行する症例が，現在においてもなお少なからず 存在することを意味している.

今回われわれは，当科で経験した深頸部感染症症例に ついて, 重症度に影響を与える要因について検討したの で文献的考察も含め報告する。

\section{対象と方法}

1982 年 1 月から 2001 年 12 月までの 20 年間に山形大 学医学部附属病院耳鼻咽喉科で入院治療を行った深頸部 感染症症例 50 例を対象とした.

内訳は男性 31 例, 女性 19 例で, 年齢は $2 \sim 88$ 歳, 平
均 45.8 歳であった.

疾患の急性期と考えられる期間は2週間程度であるが， 急性期内に入院治療を終了した症例を軽症例, 入院治療 に 2 週間以上を要した症例は重症例と定義し, 重症度の 基準とした. 今回樑頸部感染症の重症度に影響する要因 を検討するために, 前述の対象を以下の 2 群に分類した.

A 群：入院治療期間が 2 週間未満の軽症症例群 33 例

B 群：入院治療期間が 2 週間以上の重症症例群 17 例

$\mathrm{A}$ 群の内訳は男性 21 例 (63.6\%), 女性 12 例 (36.4\%) で, 年齢は $2 \sim 88$ 歳, 平均 37.9 歳, 入院日数は $2 \sim 12$ 日, 平均 6.8 日であった。

B 群の内訳は男性 10 例（58.8\%), 女性 7 例 (41.2\%) で, 年齢は $38 \sim 74$ 歳, 平均 60.9 歳, 入院日数は $16 \sim$ 107 日, 平均 43.5 日であった。

2 群間で患者背景（年齢，基礎疾患，病歴）, 樑頸部感 染症に至った原因疾患と起炎菌, 膿瘍の有無と解剖学的 位置, 治療の方法と使用抗生剂について比較検討した。 起炎菌は可能な限り好気，嫌気の両条件で培養し同定 
した. 深本ら ${ }^{23)}$ は深頸部感染症の進展度分類において 膿瘍と舌骨との位置関係が重要なポイントであり, 舌骨 下に進展したものほど病期が進行した症例であると報告 している.今回はこれに従い, 膿瘍の解剖学的位置につ いての検討では舌骨を境界にした膿瘍の相対的位置関係 を評価した。

年齢, 症状初発から来院までの期間で 2 群の比較には Mann-Whitney U-test を用い, 基礎疾患, 病歴, 膿瘍の位 置による 2 群の比較には $\chi^{2}$ 検定を用い統計学的に検討し た.いずれの検討も $\mathrm{P}$ 值が 0.05 未満で有意差ありとした.

1. 患者背景

\section{結 果}

1）年齢

図 1 亿症例の年齢分布を示した. 30 歳までの若・青年 層と 50 歳以上の壮・高年層の 2 つの年齢層で症例が多い 傾向にあった。

図 2 に症例の年齢分布における 2 群の割合を示した. $\mathrm{A}$ 群ではいずれの年齢帯においても認められるが比較的
若年層に多い印象であった。これとは逆に B 群は中高年 以降にのみ分布し，年齢を追うごとに症例数が増加して いた. 図 3 に 2 群の平均年齢の比較を示した. A 群は 37.9 歳, B 群注 60.9 歳であり, 統計学的に両群間に有 意差を認めた。 以上より高齢になるほど重症深頸部感染 症に陥りやすいと考えられた。

2）基礎疾患

糖尿病については, A 群では 9 例 $(27.3 \%)$ あり, B 群では 8 例 $(47.1 \%)$ あった. 糖尿病罹患率は，やや B 群で高い傾向があるが， $\chi^{2}$ 検定で糖尿病の有無による重 症度への影響をみてみると，有意な関係はないことがわ かった。

$\mathrm{A}$ 群では糖尿病以外に易感染性に影響を与える基礎疾 患の合併症はなかったが，B 群ではそのほかに慢性関節 リウマチで免疫抑制剂を使用していた症例が 1 例, 大動 脈炎症候群でステロイドを使用していた症例が 1 例あっ た.これらはいずれも糖尿病との合併はなかった。

3) 病歴

発症から初診までの期間について 2 群の比較を図 4 に

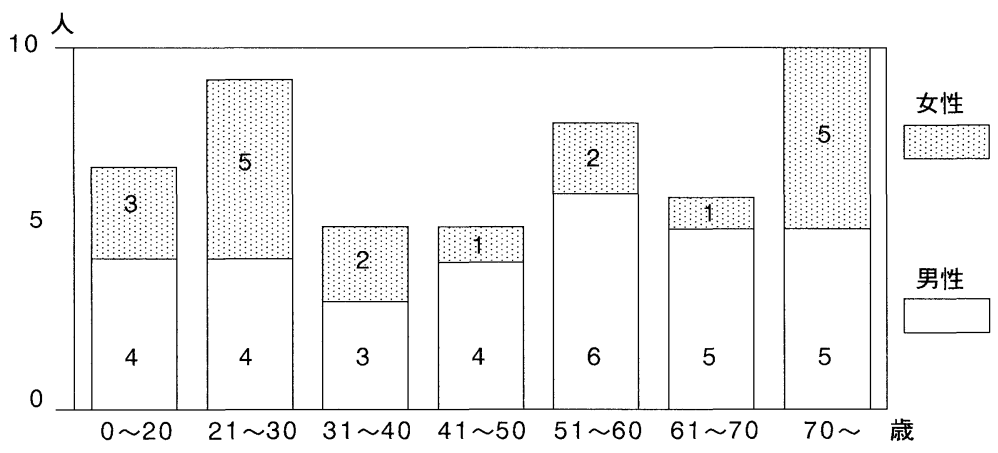

図 1 年齢分布と性別

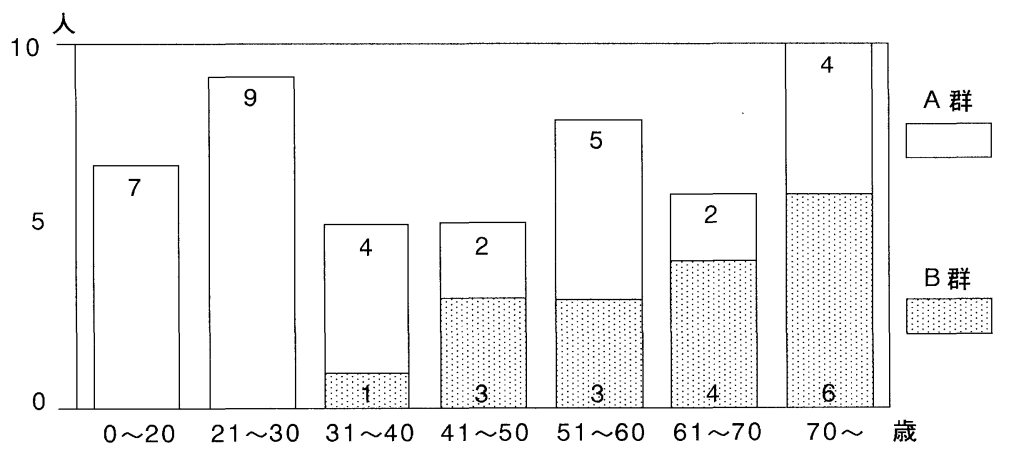

図 2 年齢分布における 2 群の割合 


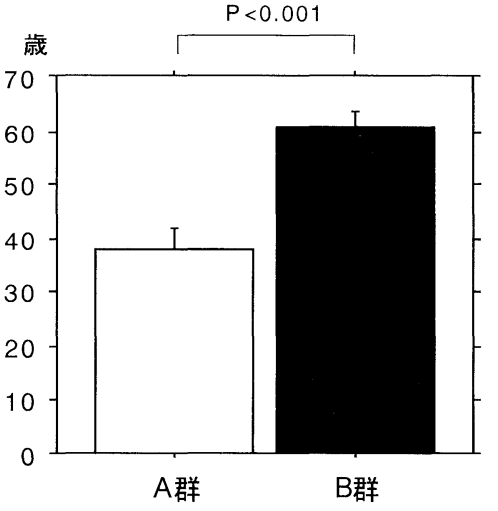

図 3 平均年齢の比較

示した. A 群では 8.7 日, B 群では 15 日と A 群のほぼ 2 倍であった．統計学的にも 2 群に有意差を認めた。 また 当科初診までに他の医療機関で治療を受けていた症例 は，A 群で 25 例 (75. 8\%)，B 群で 16 例 (94.1\%) で あった. 前医治療の有無は統計学的に差は認めなかった.

2. 原因疾患と起炎菌

1）原因疾患

2 群の深頸部感染症に至った原因疾患の内訳を図 5 に 示した. $\mathrm{A}$ 群では扁桃炎・扁桃周囲炎の割合が最も高く 15 例 $(45.5 \%), \mathrm{B}$ 群では歯歯・歯科治療後が最も高く 5 例 (29.4\%) であった. A 群では全例原因疾患が同定 されたが，B 群の 4 例（23.5\%）では原因疾患を同定す ることができなかった。これらの症例はいずれも発症か ら受診までの経過が長く, 症状が進行したため原因が不 明となった症例であった。

2）起炎菌

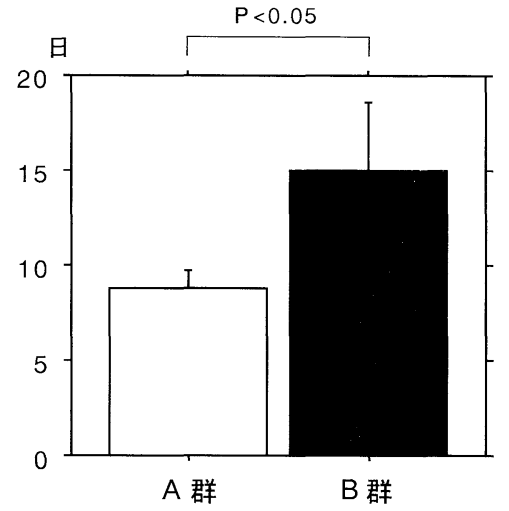

図 4 発症から初診までの期間の比較

起炎菌の内訳を表 1 亿示した. 両群とも起炎菌の検出 率は低く, A 群で $69.7 \%$, B 群で $64.7 \%$ であった。 検出 菌は両者とも Staphylococcus sp., Streptococcus sp. もしくは Enterococcus sp. が約 7割を占め, 内訳に大きな差は認めら れなかった. 諸家の報告で深頸部感染症の起炎菌の一つ と重要視されている嫌気性菌は1例も検出されなかった。

3. 膿瘍の有無と位置

樑頸部感染症症例 50 例のなかで膿瘍形成を認めた症例 は，45 例（90\%）であった。 A 群では 29 例（87.9\%), B 群では 16 例 (94.1\%) であった. 膿瘍の解剖学的位置 については, A 群では膿瘍形成症例 29 例中, 舌骨下に進 展したものが 4 例 (13.8\%), B 群では 16 例中 12 例 (75.0 \%) であった。 これら当科の治験例でも，統計学的にも 有意に膿瘍の舌骨下進展例が重症化することを示した.

4. 治療方法

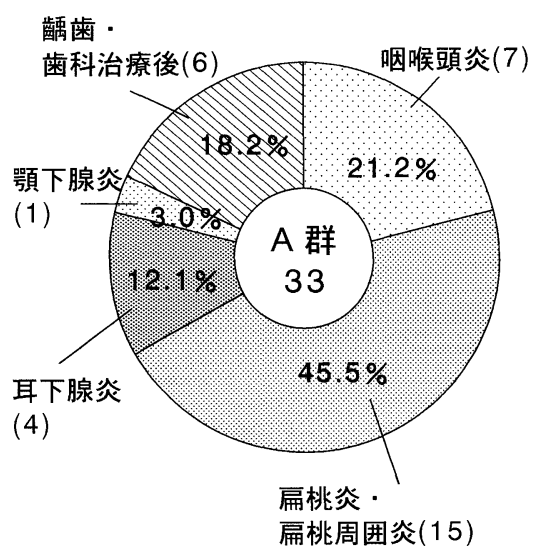

図 5 深頸部感染症の誘因疾患

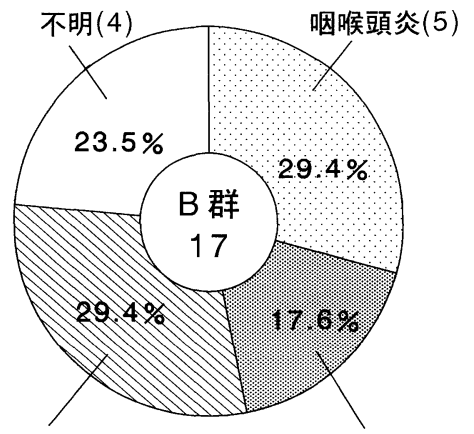

齥歯・

耳下腺炎(3) 
表 1 検出菌

\begin{tabular}{lcc}
\hline \hline & A 群 & B 群 \\
\hline Staphylococcus sp. & 2 & 1 \\
Streptococcus sp. & 3 & 2 \\
Enterococcus sp. & 2 & 1 \\
Klebsiella sp. & 1 & \\
Haemophilus sp. & 1 & \\
Pseudmonas sp. & 1 & \\
Corynebacterium sp. & & 1 \\
Propionibacterium sp. & & 1 \\
不明 & 23 & 11 \\
\hline \multicolumn{1}{c}{ 計 } & 33 & 17
\end{tabular}

1）処置

2 群の治療方法の内訳を図 6 亿示した． A 群では保存 的治療や穿刺で済んだものが 28 例 (84.8\%), 外科的治 療を要したものは 5 例（15.2\%）だけだったのに対し， B 群では逆に保存的治療で済んだものが 3 例 (17.6\%)だ けであり，14 例 (82.4\%) では何らかの外科的治療を施 行している.さらにドレナージを要したものが 9 例(52.9 \%）と約半数を占めた．また，気管切開を行い，気道確 保した症例は A 群では 1 例（3.0\%）だけであったのに 対し，B 群では 10 例 (58.8\%) であった。

2）使用抗生剂

抗生剤の選択（表 2）については両群とも大きな差は なく, 基本的な考え方として, 広域ペニシリン・セフェ ム系抗生剤に加え, 嫌気性細菌に対するクリンダマイシ ンを併用している.

$\mathrm{B}$ 群においては，抗菌スペクトラムの広いカルバペネ
表 2 使用抗生剂

\begin{tabular}{lcc}
\hline \hline & $\mathrm{A}$ 群 & $\mathrm{B}$ 群 \\
\hline PIPC/CLDM & 8 & 5 \\
CEZ/CLDM & 3 & \\
CTM & 5 & \\
CTM/CLDM & 5 & \\
FMOX/CLDM & 8 & 5 \\
PAPM/BP & & 4 \\
その他 & 4 & 3 \\
\hline \multicolumn{1}{c}{$\quad$ 計 } & 33 & 17
\end{tabular}

ム系抗生剂を使用することもあった．しかしこれらの症 例は広域ペニシリン，セフェム系抗生剂の効果が低い場 合に変更されたものが大半であり, 治療開始から使用し た症例は 1 例のみであった。

\section{考察}

抗生剤の普及により梁頸部感染症の頻度が低くなった といわれている今日でも, 重症の深頸部膿瘍や縱隔膿瘍 の報告例は少なくない4).これは発症頻度が減少しても 条件がそろうと深頸部感染症が重症化する可能性がある ことを示している.

今回, 深頸部感染症が重症化する条件を検討するため に，重症度の重要なパラメータの一つである入院期間に より，対象を入院期間 2 週間以内 (A 群) と入院期間 2 週間以上 (B 群) に分類した. この 2 群に分かれる条件 が重症化する因子となり, 深頸部感染症治療上の注意点 になると考えられる．以下は重症化する因子について

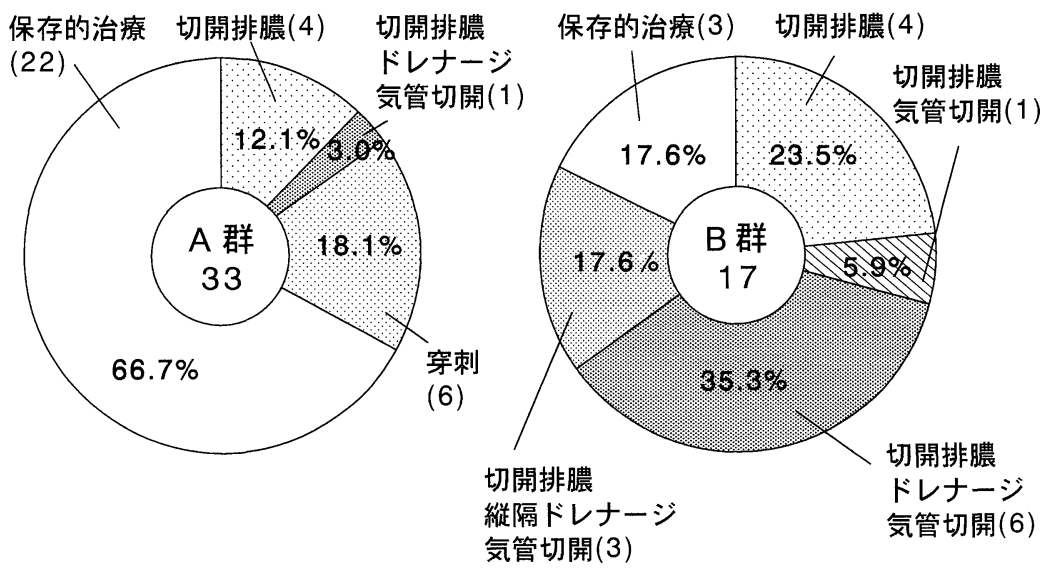

図 6 治療方法 
個々に考察を加えた.

1. 患者背景

1）年齢

結果でも示したように，B 群の平均年齢が $\mathrm{A}$ 群より有 意に高かったことから, 高年齢は深頸部感染症の重症化 する条件の一つと考えられる. 石永ら ${ }^{5)}$ は 79 例の深頸部 膿瘍の検討で高齢であることが発症要因とは考えられな いと報告している. 長崎ら ${ }^{6)}$ は 67 例の縱隔進展深頸部感 染症症例の検討から縱隔に進展した深頸部感染症症例の なかで，死亡例は高年齢症例に多く，予後不良因子であ ると報告している．当科治験例でも死亡例は 1 例あった が，B 群で 74 歳の高齢者であった，以上のことから，高 年齢は深頸部感染症の発症因子ではなく，重症化因子な いしは予後不良因子と考光られる。

2）基礎疾患

これまでの報告で基礎疾患としての糖尿病は宿主の易 感染性にかかわり発症因子として重要であるといわれて いる2035). 当科治験例でも 17 例 (34.0\%) に合併してお り，深本ら ${ }^{23)}$ の報告とほぼ同様の結果であった. 結果で も示したようにA 群と比較して B 群の方に合併率が高い が, 重症化する危険度としては有意な差はなく, 統計学 的に糖尿病そのものは重症化因子とは結論することがで きなかった. 安藤ら 7) の深頸部膿崵の文献的考察からも 糖尿病は予後決定因子とは必ずしもならないという報告 があり，当科治験例の検討とも合致している.

深頸部膿瘍の縦隔進展例における死亡症例の検討で, 慢性肝不全，慢性腎不全合併症例では致死率が高いと報 告されている7)。当科で経験した前述の死亡例でも慢性 関節リウマチに対する非ステロイド性消炎剤を長期使用 したことによる腎機能低下が合併していた，以上のこと から基礎疾患の重症化因子は宿主の易感染性にかかわる ものといらよりは予備能力にかかわるものが考えられ る.

\section{3) 病歴}

当科における墚頸部感染症患者は, 大学病院という施 設の特色か他施設での治療で改善しないため紹介され受 診することが多く，来院・治療開始までに要した期間は 秋定ら ${ }^{4)}$ や奥野ら ${ }^{8)}$ の報告に比べて長かった. 来院まで の日数が， A， B 群間の比較で B 群が倍近く多いことか ら，これが重症度に影響を与える要因と考えられる．さ らに当然のことであるが前医で治療歴のある症例のほと んどが内服抗生剂の治療歴があることと併せて考える
と，深頸部感染症の重症度を上げないためには，初期治 療で効果の低い場合, 速やかに治療手段, 治療機関を変 更することが肝要であると思われる。

2. 原因疾患と起因菌

1）原因疾患

A， B 群間に原因疾患の内容の大きな隔たりはないが， 注目すべき点は B 群で荋歯・歯科治療後が原因となる症 例が多いとことである。これらの症例のなかで糖尿病な ぞの易感染性に影響を与える基礎疾患を持つものは 5 例 中 1 例のみであり，その他 $\mathrm{B}$ 群にみられた原因疾患のな

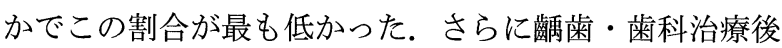
の症例の平均年齢はその他の疾患群のなかで最も低かっ た. よって唃歯・歯科治療後が症例の易感染性や年齢に 関係なく単独でも十分に重症化の要因になりらるものと 考えられた。

2) 起炎菌

両群とも起炎菌の検出率が低いことや起炎菌として重 視される嫌気性菌が1例も検出されていないこともあり， 起炎菌において重症化の要因について言及することは難 しいが，今回の検討では検出された菌種が重症度に影響 を与えることはなかった，検出されなかった症例におい ては嫌気性菌が起炎菌となっていた可能性も考えられる が，検出された症例と検出されなかった症例の入院期間 に有意な差がなかったことから，菌種が重症度に影響を 与えるとは考えにくい，今後起炎菌の重症度への影響を 明確にするために，起炎菌同定のための検体採取には細 心の注意を要すると考えられた。

3. 膿瘍の解剖学的位置

舌骨は深頸部間隙を区分する上でも重要な構造物だと いわれている，舌骨を境にして上方では傍咽頭陌，咀嚼 筋隙，耳下腺隙，顎下隙，煩筋陌，咽頭内隙など間隙が 形成される，咽頭・口腔などを起源とする炎症の多くは これらの間隙に波及し, 高度になると膿瘍を形成する。 舌骨はこれら炎症・膿瘍が降下する通行路を遮断する位 置にあり，炎症・膿瘍が舌骨を越えると舌骨下間隙の内 臓隙, 前頸陌, 胸骨上隙に進展し最終的には縦隔に至る. 炎症・膿瘍が縦隔に至った場合は生命にも影響を与える ような重篤な状態に陥る．以上のような解剖学的考察や 当科における治験例の結果から, 深頸部感染症の重症度 が膿瘍の舌骨との相対的位置関係により規定できる可能 性があると考えられる. 深本ら ${ }^{23)}$ や石永ら ${ }^{5)}$ が指摘して いるように CT 等の画像診断を早期に行うことにより， 
深頸部感染症の進行度を診断し病状を進めないように治 療方針を早急に決定することが重要である910).

4. 治療方法

B 群では何らかの外科的治療を要したものが $80 \%$ 超 え,気道確保を要したものは約 $60 \%$ あった。これは深頸 部感染症症例が重症化した結果として治療内容がより侵 襲の強い治療法を選択せざるを得なかったことを示して いる．ただし，切開排膿されるべきところがされていな かったのか，あるいは炎症が強く新たに炎症が及んだか は不明であるが,外科的治療が 2 度に及ぶものもあった。 画像上の膿瘍位置を十分評価した上で Levitt ${ }^{11)}$ が報告し たように各間隙ごとに根治的な頸部膿瘍開放を基本とし て縱隔洞に至る間隙まで十分に開放することが重要であ り，排膿の際には思い切って大きな切開をすることが結 局は治癒を早めることになるのではないかと思われた。

\section{まとめ}

1） 1982 年 1 月から 2001 年 12 月までの間に山形大学 医学部附属病院耳鼻咽喉科で入院治療を要した深頸部感 染症50例を対象に深頸部感染症の重症度に影響を与える 要因について検討した。

2）梁頸部感染症の重症度に影響を与える要因として, 年齢，発症から初診までの期間，合併症の有無，膿瘍形 成の位置が考えられた。

\section{参考文献}

1）保喜克文, 朝倉光司, 形浦昭克, 他 : 重篤な症状を呈した 頸部膿瘍 4 例. 日耳鼻 $90 ： 1915 \sim 1921 ， 1987$.

2）深本克彦，杉田麟也：急性扁桃炎に続発した頸部縦隔膿瘍 の 1 例一その治療法の検討一. 日耳鼻 93:884〜893, 1990.

3）深本克彦, 市川銀一郎 : 進展した深頸部感染症の治療一文 献的考察一. 耳鼻臨床 $88: 773 \sim 779,1995$.

4）秋定 健, 山本英一, 佐藤幸弘, 他：当科における深頸部 感染症の検討. 耳鼻臨床 補 $69: 131 \sim 137,1994$.

5）石永一, 加藤昭彦, 山田弘之 : 頭頸部膿瘍 79 例の臨床的 検討. 耳鼻臨床 $91: 1063 \sim 1067,1998$.

6）長崎正男, 將積日出夫, 中川 肇, 他：縦隔に進展した深 頸部感染症の 3 例. 耳鼻臨床 $91: 727 \sim 733,1998$.

7）安藤敬子, 佐藤公輝, 田淵伴秀 : 深頸部膿瘍の 3 例一その 縦隔洞進展についての検討一. 耳鼻 $38: 214 \sim 219,1992$.

8）奥野敬一郎, 金井憲一, 渡辺尚彦, 他：深頸部膿場一当科 における 9 年間, 37 例の検討一. 耳喉頭頸 69:67〜 71, 1997 .

9）門脇敬一：Deep neck infection 10 例の経験. 日耳鼻感染誌 $10: 38 \sim 41,1992$.

10）八木昌人, 田山二朗, 市村恵一: Deep neck infection一CT の有用性と切開排膿の是非に関する考察一. 耳鼻 $35: 1$ 6, 1989 .

11) Levitt GW : The surgical treatment of deep neck infections. Laryngoscope $81: 403 \sim 411,1971$.

原稿受付: 平成 15 年 3 月 7 日 原稿採択：平成 15 年 5 月 7 日 別刷請求先 : 那須 隆 于990-9585 山形市飯田西2-2-2 山形大学医学部耳鼻咽喉科学教室 